\title{
Toll-like receptor 4 mediates ischemia/reperfusion injury of the heart
}

\author{
Albert J. Chong, MD \\ Akira Shimamoto, $\mathrm{MD}, \mathrm{PhD}^{\mathrm{a}}$ \\ Craig R. Hampton, $\mathrm{MD}^{\mathrm{a}}$ \\ Hiroo Takayama, MDa \\ Denise J. Spring, $\mathrm{PhD}^{\mathrm{a}}$ \\ Christine L. Rothnie, BS ${ }^{\mathrm{a}}$ \\ Masaki Yada, MD ${ }^{\mathrm{b}}$ \\ Timothy H. Pohlman, MD \\ Edward D. Verrier, $\mathrm{MD}^{\mathrm{a}}$
}

From the Division of Cardiothoracic Surgery, Department of Surgery, The University of Washington, Seattle, Wash, ${ }^{\mathrm{a}}$ and the Department of Thoracic and Cardiovascular Surgery, Mie University, Tsu, Japan. ${ }^{\text {b }}$

This work was supported in part by National Institutes of Health grant R01 HL61767, a Bayer Corporation Research Fellowship grant (2002-2003), and a Grantin-Aid for Scientific Research (14370408) from the Japanese Ministry of Education, Culture, Sports, Science and Technology.

Read at the Twenty-ninth Annual Meeting of The Western Thoracic Surgical Association, Carlsbad, Calif, June 18-21, 2003.

Received for publication June 17, 2003; revisions requested Oct 17, 2003; revisions received Nov 5, 2003; accepted for publication Dec 2, 2003.

Address for reprints: Timothy H. Pohlman, MD, Department of Surgery, Division of Cardiothoracic Surgery, University of Washington, Box 356310, 1959 NE Pacific St, Seattle, WA 98195 (E-mail: tpohlman@u.washington.edu).

J Thorac Cardiovasc Surg 2004;128:170-9

$0022-5223 / \$ 30.00$

Copyright ( $\odot 2003$ by The American Association for Thoracic Surgery

doi:10.1016/j.jtcvs.2003.11.036
Background: Restoration of blood flow to the ischemic heart may paradoxically exacerbate tissue injury (ischemia/reperfusion injury). Toll-like receptor 4, expressed on several cell types, including cardiomyocytes, is a mediator of the host inflammatory response to infection. Because ischemia/reperfusion injury is characterized by an acute inflammatory reaction, we investigated toll-like receptor 4 activation in a murine model of regional myocardial ischemia/reperfusion injury. We used $\mathrm{C} 3 \mathrm{H} / \mathrm{HeJ}$ mice, which express a nonfunctional toll-like receptor 4 , to assess the pertinence of this receptor to tissue injury after reperfusion of ischemic myocardium.

Methods: Wild-type mice $(\mathrm{C} 3 \mathrm{H} / \mathrm{HeN})$ or toll-like receptor 4 mutant mice $(\mathrm{C} 3 \mathrm{H} / \mathrm{HeJ})$ were subjected to 60 minutes of regional myocardial ischemia followed by 2 hours of reperfusion. At the end of reperfusion, the area at risk and the myocardial infarct size were measured as the end point of myocardial ischemia/reperfusion injury. Myocardial mitogen-activated protein kinase activation was measured by Western blotting, and nuclear translocation of nuclear factor- $\kappa \mathrm{B}$ and activator protein-1 was determined by electrophoretic mobility shift assay. Ischemia/reperfusion-injured myocardium was also assessed by ribonuclease protection assay for expression of inflammatory mediators (tumor necrosis factor- $\alpha$, interleukin- $1 \beta$, monocyte chemotactic factor-1, and interleukin-6).

Results: The area at risk was similar for all groups after myocardial ischemia/ reperfusion injury. There was a $40 \%$ reduction in infarct size (as a percentage of the area at risk) in $\mathrm{C} 3 \mathrm{H} / \mathrm{HeJ}$ mice compared with $\mathrm{C} 3 \mathrm{H} / \mathrm{HeN}$ mice $(P=.001)$. Within the myocardium, significant activation of c-Jun N-terminal kinase, p38, and extracellular signal-regulated kinase was observed in both strains after ischemia and during reperfusion as compared with an absence of mitogen-activated protein kinase activation during sham operations; however, c-Jun N-terminal kinase activity, but not $\mathrm{p} 38$ or extracellular signal-regulated kinase activity, was significantly reduced in $\mathrm{C} 3 \mathrm{H} / \mathrm{HeJ}$ mice $(P<.05)$. In both groups, nuclear factor- $\kappa \mathrm{B}$ and activator protein-1 nuclear translocation occurred in the myocardium during myocardial ischemia/ reperfusion injury, but, by densitometric analysis, nuclear translocation of nuclear factor- $\kappa \mathrm{B}$ and activator protein-1 was significantly decreased in $\mathrm{C} 3 \mathrm{H} / \mathrm{HeJ}$ mice compared with $\mathrm{C} 3 \mathrm{H} / \mathrm{HeN}$ mice. Interleukin- $1 \beta$, monocyte chemotactic factor- 1 , and interleukin-6 were detectable in reperfused ischemic myocardium but were not detected in sham-operated myocardium; the expression of each of these mediators was significantly decreased in the myocardial tissue of $\mathrm{C} 3 \mathrm{H} / \mathrm{HeJ}$ mice when compared with expression in the control $\mathrm{C} 3 \mathrm{H} / \mathrm{HeN}$ mouse strain. 
Conclusions: Our data suggest that toll-like receptor 4 may mediate, at least in part, myocardial ischemia/reperfusion injury. Inhibition of toll-like receptor 4 activation may be a potential therapeutic target to attenuate ischemia/reperfusion-induced tissue damage in the clinical setting.

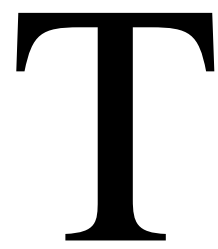

oll-like receptors (TLRs) have a central role in innate immunity and inflammation. ${ }^{1}$ Among the family of TLRs, TLR4 has been the focus of particular interest since its recognition as a receptor for lipopolysaccharide (LPS; endotoxin). ${ }^{2-4}$ Of interest, TLR4 seems to bind molecular structures other than LPS, such as paclitaxel, fibronectin, fibrin and fibrinogen, extracellular matrix fragments, and heat-shock proteins 60 (HSP-60) and 70 (HSP-70). ${ }^{5-11}$ Thus, TLR4 may be activated in conditions other than gram-negative infection.

The cytoplasmic portions of TLRs share structural and signaling similarities with the receptor for interleukin (IL)$1 .{ }^{12}$ With binding of ligand, TLR4 activates signaling pathways that lead to nuclear translocation of nuclear factor (NF) $-\kappa \mathrm{B}$, which promotes the expression of several inflammatory mediators, including tumor necrosis factor (TNF)- $\alpha$, IL-1 $\beta$, IL-6, and IL-8. ${ }^{13-15}$ TLR4, initially demonstrated in monocytes, has since been shown to be expressed in other tissues, including the heart. ${ }^{16}$ Injured human and murine myocardium have intense TLR4 expression. ${ }^{15}$ It is interesting to note that the expression of TLR4 within the heart is mostly in cardiomyocytes-cells that lack any identified role in immunity.

TLR4 is linked to mitogen-activated protein kinase (MAPK) activation. MAPKs, such as p38 and c-Jun Nterminal kinase (JNK), are activated during myocardial ischemia/reperfusion (I/R) injury (see review ${ }^{17}$ ), an event that induces an acute inflammatory reaction. We therefore hypothesized that TLR4, which elicits an inflammatory response on stimulation, mediates I/R injury in the heart. To test this hypothesis, we compared myocardial $\mathrm{I} / \mathrm{R}$ injury between 2 strains of mice: $\mathrm{C} 3 \mathrm{H} / \mathrm{HeJ}$ and $\mathrm{C} 3 \mathrm{H} / \mathrm{HeN}$. $\mathrm{C} 3 \mathrm{H} /$ $\mathrm{HeJ}$ is a strain of mice that contains a missense mutation in the intracellular portion of TLR4 that prevents the activation of the remainder of the downstream signaling pathways., ${ }^{2,3}$ $\mathrm{C} 3 \mathrm{H} / \mathrm{HeN}$ is the mouse strain used as a wild-type control. We demonstrated in this study that after 60 minutes of regional myocardial ischemia, $\mathrm{C} 3 \mathrm{H} / \mathrm{HeJ}$ mice have a smaller area of infarction after reperfusion than $\mathrm{C} 3 \mathrm{H} / \mathrm{HeN}$ mice: this suggests participation of TLR4 in myocardial I/R injury.

\section{Materials and Methods}

\section{Experimental Groups}

$\mathrm{C} 3 \mathrm{H} / \mathrm{HeJ}$ mutant mice or $\mathrm{C} 3 \mathrm{H} / \mathrm{HeN}$ control mice were subjected to 60 minutes of regional myocardial ischemia followed by reperfu- sion (Figure 1). Infarction size and cytokine messenger RNA (mRNA) levels were measured at the end of the 120-minute reperfusion period. Three MAPKs (p38 MAPK, JNK, and extracellular signal-regulated kinase [ERK]) and two transcription factors (NF- $\kappa$ B and activator protein $[\mathrm{AP}]-1)$ were examined after 15 and 30 minutes of reperfusion, respectively.

\section{Murine Model of Regional Myocardial I/R}

A murine model of in situ regional myocardial I/R injury was used, as previously described. ${ }^{18}$ All animals were maintained in accordance with the Guide for the Care and Use of Laboratory Animals published by the US National Institutes of Health (NIH; NIH Publication no. 85-23, revised 1996) and also with the guidelines of the Animal Care and Use Committee of the University of Washington. Before experimentation, all animals were housed in a room with a $22^{\circ} \mathrm{C}$ temperature, $41 \%$ relative humidity, and $12-/$ 12-hour light/dark cycles in the animal care wing and were allowed access to water and food ad libitum.

General anesthesia was achieved with intraperitoneal pentobarbital sodium (Abbott Laboratories, North Chicago, Ill; $100 \mathrm{mg} / \mathrm{kg}$ ). In all groups, anesthesia was confirmed by lack of a foot withdrawal reflex. A middle cervical incision was made, and a section of PE-90 tubing was passed through the exposed trachea until the tip was $2 \mathrm{~mm}$ below the larynx. Mechanical ventilation (model 687 mouse ventilator; Harvard Apparatus, Holliston, Mass) was set to ensure normal physiologic parameters after serial blood gases were obtained in pilot studies. Temperature was monitored via a rectal temperature probe (YSI Series 400 temperature probe; Yellow Springs, Ohio) and maintained at $37^{\circ} \mathrm{C}$ with a heating lamp. A left parasternotomy was performed under the dissecting microscope (Zeiss Operating Microscope, OPMI 6-SDFC; Oberkochen, Germany) through careful division of 3 ribs in a cephalocaudal direction parallel to the sternum, and the pericardium was reflected to expose the heart. A 7-0 silk suture (Tyco Health Care, US Surgical, Norwalk, Conn) on an HE-7 needle was passed behind the left anterior descending (LAD) artery just below the left atrial appendage. A Rumel-type snare was created by passing both ends of the suture through the tip of a 22-gauge angiocatheter that could then be tightened and released by sliding a Voss clip down on the angiocatheter for ischemia and reperfusion, respectively. Effective occlusion of the LAD was visually confirmed by blanching of the left ventricle (LV) and subsequent hyperemia with release of the snare. After 60 minutes of ischemia, the occlusive snare was released to allow reperfusion of up to 2 hours (Figure 1). Sham mice underwent the same surgical procedures except that the suture was not snared. At the completion of reperfusion, hearts were rapidly explanted for molecular analyses. The LV was dissected free, rinsed in $0.9 \%$ saline, snap-frozen in liquid nitrogen, and stored at $-80^{\circ} \mathrm{C}$ until subsequent analysis. Hearts that were 


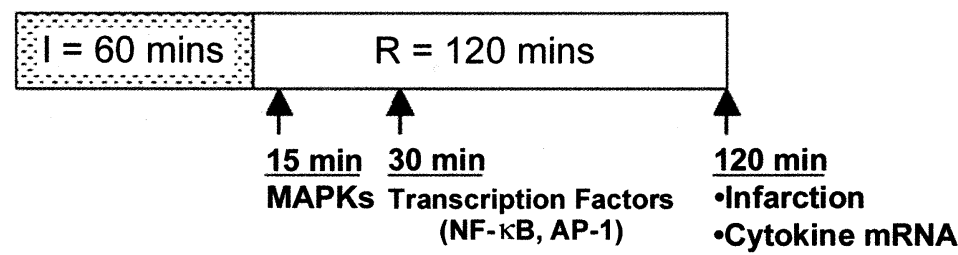

Figure 1. Experimental groups. Wild-type control $\mathrm{C} 3 \mathrm{H} / \mathrm{HeN}$ mice and TLR4 mutant $\mathrm{C} 3 \mathrm{H} / \mathrm{HeJ}$ mice underwent 60 minutes of regional myocardial ischemia and 120 minutes of reperfusion. MAPKs (p38 MAPK, JNK, and ERK), transcription factors (NF- $\kappa$ B and AP-1), and infarction size and cytokine mRNA levels were measured at 15, 30, and 120 minutes, respectively.

analyzed for area at risk (AAR) and infarct size were harvested after 2 hours of reperfusion.

\section{Determination of AAR and Infarct Size}

At the completion of the experimental protocol, the LAD was reoccluded, and $4 \%$ Evans blue dye was injected into the aortic root to determine AAR (unstained area). Hearts were then explanted, rinsed in $0.9 \%$ normal saline, embedded in $1 \%$ agarose gel (UltraPure agarose; Invitrogen, Carlsbad, Calif) in phosphate-buffered saline ( $\mathrm{pH} 7.4)$, and sliced into 1-mm-thick sections parallel to the atrioventricular groove. Each heart section was incubated in $1 \%$ triphenyltetrazolium chloride at $37^{\circ} \mathrm{C}$ for 10 minutes and in $10 \%$ formalin for 24 hours and was then weighed and photographed with a digital camera (Coolpix 950; Nikon, Tokyo, Japan). AAR and infarct area (unstained by triphenyltetrazolium chloride) were measured by using computer planimetry (ImageJ 1.21; National Institutes of Health public domain, http://rsb.info.nih.gov/ $\mathrm{ij}$ ), and the average values were recorded. These areas were measured in a blinded fashion by an observer unaware of the experimental groups. Infarct volumes were calculated and expressed as a percentage of AAR.

\section{Preparation of Cytosolic and Nuclear Proteins}

Frozen-tissue samples of the LV were ground into a fine powder and homogenized in ice-cold lysis buffer. The homogenates were centrifuged at $15,000 \mathrm{~g}$ at $4^{\circ} \mathrm{C}$ for 10 minutes, and the supernatants were collected as whole myocardial extracts.

For nuclear extractions, heart tissue samples were suspended in an ice-cold low-salt buffer containing 0.6\% Nonidet P-40 (Sigma, St Louis, Mo). The solution was homogenized and centrifuged at $350 \mathrm{~g}$ at $4^{\circ} \mathrm{C}$ for 20 seconds. The pellet was discarded, and the supernatant was centrifuged again at $15,000 \mathrm{~g}$ at $4^{\circ} \mathrm{C}$ for $10 \mathrm{~min}$ utes. The supernatant was saved as cytosolic extract; the pellet was suspended in $40 \mu \mathrm{L}$ of high-salt buffer* at $4^{\circ} \mathrm{C}$ for 20 minutes. This solution was then centrifuged at $15,000 \mathrm{~g}$ at $4^{\circ} \mathrm{C}$ for 10 minutes, and the supernatant was collected as the nuclear protein extract. Final protein concentrations of these extracts were determined by using the bicinchoninic acid method (Pierce Biotechnology, Inc, Rockford, Ill). Samples were stored at $-80^{\circ} \mathrm{C}$ until the time of assay.

*Hepes $20 \mathrm{mmol} / \mathrm{L}, \mathrm{MgCl}_{2} 1.5 \mathrm{mmol} / \mathrm{L}, \mathrm{NaCl} 420 \mathrm{mmol} / \mathrm{L}$, EDTA 0.2 $\mathrm{mmol} / \mathrm{L}$, and glycerol $25 \%$.

\section{Western Immunoblotting Assay for Phosphorylation of MAPKs}

Whole-cell myocardial extracts were resolved on $10 \%$ to $15 \%$ sodium dodecyl sulfate-polyacrylamide electrophoretic gels as previously described. ${ }^{19}$ Gels were transferred to polyvinylidene difluoride membranes, washed, and incubated with primary antibodies for the activated, phosphorylated forms of p38, ERK, and JNK (1:1000; Cell Signaling Technology Inc, Beverly, Mass). Blots were also reprobed with antibody for total protein $(\mathrm{p} 38$, ERK, or JNK). Blots were incubated with horseradish peroxidaseconjugated secondary antibody (1:2000) in blocking buffer with gentle agitation for 1 hour at room temperature. Immunoreactivity was detected with enhanced chemiluminescence (Pierce) and quantitated with densitometry (NIH Image 1.62). The ratio of phosphorylated- to total MAPK immunoreactivity was determined for each sample, and the results were expressed as fold activation over a control.

\section{Electrophoretic Mobility Shift Assays for NF- $\kappa$ B and AP-1 Activity}

Electrophoretic mobility shift assays (EMSA) using an oligonucleotide containing the consensus sequence motifs for NF- $\kappa \mathrm{B}$ binding (5'-AGTTGAGGGGACTTTCCCAGGC-3') and AP-1 binding (5'CGCTTGATGAGTCAGCCGGAA-3'; Promega, Madison, Wis) were performed as previously described. ${ }^{20}$ Densitometry was performed with NIH Image 1.62. The results were expressed as fold activation over control.

\section{Ribonuclease Protection Assay}

Total RNA was isolated from frozen tissue samples by the guanidinium thiocyanate-phenol-chloroform method. RNA integrity was confirmed by agarose gel electrophoresis and quantitated by optical density measurements at $260 \mathrm{~nm}$. RNA was evaluated with an RPA III Ribonuclease Protection Assay Kit (Ambion Inc, Austin, Tex) and a customized mouse cytokines template (Riboquant Multi-Probe Template Set; BD Biosciences Pharmingen, San Diego, Calif). In vitro transcription was performed in buffer supplemented with $\left[\alpha^{32} \mathrm{P}\right]$ uridine triphosphate (PerkinElmer, Inc., Wellesley, Mass) and T7 RNA polymerase (MAXIscript T7 Kit; Ambion). Labeling efficiency was determined by measuring Chernokov activity in a scintillation counter. Each riboprobe was diluted to the optimal activity (defined by the manufacturer), added to $20 \mu \mathrm{g}$ of heart RNA, heated for 3 minutes at $95^{\circ} \mathrm{C}$, and then 
hybridized at $56^{\circ} \mathrm{C}$ overnight. After ribonuclease and proteinase $\mathrm{K}$ treatment, protected RNA hybrids were purified by phenol and chloroform extraction and ammonium acetate and ethanol precipitation and then separated by electrophoresis on 5\% polyacrylamide/8 mol/L urea gels. Gels were dried and subjected to autoradiography. Densitometric analysis was performed with NIH Image 1.62 .

\section{Statistical Analysis}

All data are expressed as mean \pm SEM. The significance of the difference between group means was analyzed by analysis of variance with post hoc comparisons by the Scheffé protected least significant difference test. All statistical analyses were performed with StatView 6.0 (SAS Institute Inc, Cary, NC).

\section{Results}

\section{Myocardial Infarction}

Wild-type $(\mathrm{C} 3 \mathrm{H} / \mathrm{HeN})$ and TLR4 mutant $(\mathrm{C} 3 \mathrm{H} / \mathrm{HeJ})$ mice underwent thoracotomy and occlusion of the LAD to induce regional I/R injury to the $\mathrm{LV}$ severe enough to produce an infarct. The AAR was defined as the area of the LV that lost perfusion during temporary occlusion of the LAD; the mean AAR was similar in both groups $(\mathrm{C} 3 \mathrm{H} / \mathrm{HeN}$ AAR, $43.9 \% \pm$ $4 \%$; C3H/HeJ AAR, $36.1 \% \pm 2 \% ; P=.10)$. Following release of the ligature after 60 minutes of ischemia, the AAR was reperfused for 2 hours, and infarct size within the AAR was expressed as a percentage of the AAR. C3H/HeN mice (wild-type TLR4) had a mean infarct size of $36.2 \% \pm$ $2.7 \%(\mathrm{n}=8)$. In contrast, $\mathrm{C} 3 \mathrm{H} / \mathrm{HeJ}$ (mutant TLR4) mice had a distinctly smaller infarct size of $22.5 \% \pm 2.4 \%(\mathrm{n}=$ 11), a difference that was highly significant $(P=.001$; Figure 2). Thus, mutation of the TLR4 gene had a protective effect during myocardial I/R injury.

\section{Activation of MAPKs}

Activation of MAPK signaling cascades downstream of TLR4 in LV myocardium from $\mathrm{C} 3 \mathrm{H} / \mathrm{HeN}(\mathrm{n}=5)$ and $\mathrm{C} 3 \mathrm{H} / \mathrm{HeJ}(\mathrm{n}=5)$ mice was compared after 60 minutes of ischemia and 15 minutes of reperfusion. In the $\mathrm{C} 3 \mathrm{H} / \mathrm{HeN}$ mice, all 3 MAPKs were activated (Figure 3, A), compared with undetectable levels in the LV myocardium of shamoperated control mice (data not shown). The activation of all 3 MAPKs was also detected in the I/R-injured myocardium of $\mathrm{C} 3 \mathrm{H} / \mathrm{HeJ}$ mice (Figure 3, A). However, densitometric analysis of immunoblots for the phosphorylated, activated form of JNK revealed significantly less activated JNK in the myocardium of $\mathrm{C} 3 \mathrm{H} / \mathrm{HeJ}$ mice (mutant TLR4) compared with levels of activated JNK in $\mathrm{C} 3 \mathrm{H} / \mathrm{HeN}$ (wild-type) I/Rinjured myocardium $(P<.05)$. Total protein loading for each kinase was controlled by immunoblotting with an antibody that recognizes the total MAPK present in the sample.

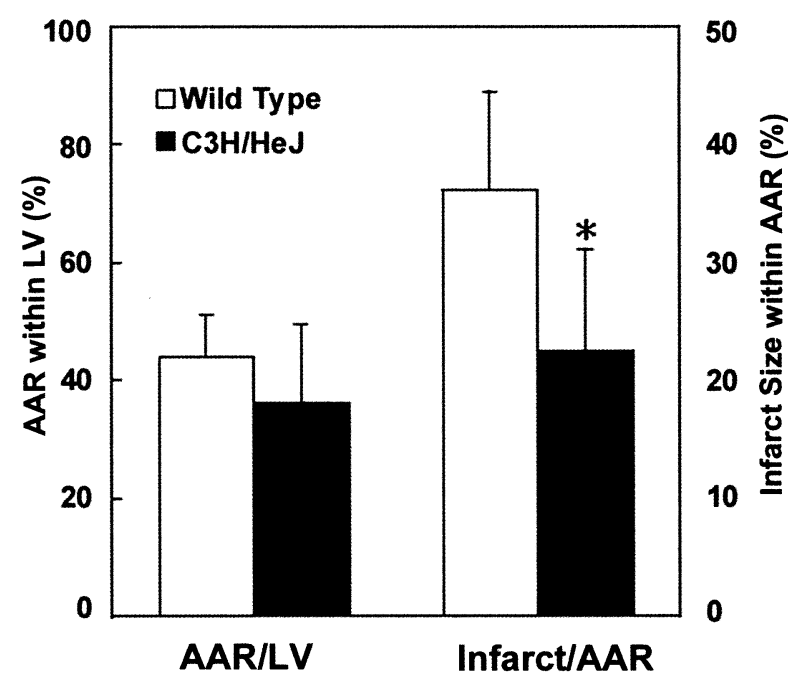

Figure 2. Myocardial infarction size. After 60 minutes of ischemia and 120 minutes of reperfusion, both $\mathrm{C} 3 \mathrm{H} / \mathrm{HeN}$ wild-type mice (WT) and C3H/HeJ TLR4 mutant mice had similar areas at risk within the LV (AAR/LV). However, the infarct size (Infarct/AAR) was $\mathbf{4 0} \%$ less in mutant compared with WT mice (WT, $36.2 \% \pm$ $2.7 \%$ infarction; mutant, $22.5 \% \pm 2.4 \%$ infarction).

Activation of Transcription Factors (NF- $\kappa$ B and AP-1) Activation of NF- $\kappa$ B and AP-1 was determined by using EMSA to measure nuclear translocation during myocardial I/R injury. EMSAs revealed activation of both $\mathrm{NF}-\kappa \mathrm{B}$ and $\mathrm{AP}-1$ in both $\mathrm{C} 3 \mathrm{H} / \mathrm{HeJ}$ and $\mathrm{C} 3 \mathrm{H} / \mathrm{HeN}$ mice. However, by densitometric analysis of the gels, with normalization of band density to total protein loaded, the apparent amounts of $\mathrm{NF}-\kappa \mathrm{B}$ and $\mathrm{AP}-1$ translocations were significantly reduced in $\mathrm{C} 3 \mathrm{H} / \mathrm{HeJ}$ mice compared with wild-type controls $(\mathrm{C} 3 \mathrm{H} / \mathrm{HeN} ; P<.05$; Figure 3 , $B)$. Neither NF- $\kappa \mathrm{B}$ activation nor AP-1 activation was observed at any point in any experiment during the reperfusion period in the sham-operated $\mathrm{C} 3 \mathrm{H} / \mathrm{HeN}$ mice (data not shown).

\section{Expression of Inflammatory Cytokines and Chemokines}

The mRNA expression of TNF, IL-1, IL-6, and monocyte chemotactic factor (MCP)-1 in cytosolic fractions of homogenized LV from sham-operated wild-type $\mathrm{C} 3 \mathrm{H} / \mathrm{HeN}$ and TLR4 mutant $\mathrm{C} 3 \mathrm{H} / \mathrm{HeJ}$ mice were examined after 60 minutes of ischemia and 120 minutes of reperfusion for each strain (Figure 4). Myocardial I/R in $\mathrm{C} 3 \mathrm{H} / \mathrm{HeN}$ mice (n $=4$ ) induced upregulation of IL-1, IL-6, and, most prominently, MCP-1 when compared with sham controls, in which accumulation of mRNA for IL-1, MCP-1, and IL-6 was only barely detectable. However, IL-1, MCP-1, and IL-6 were not detected in $\mathrm{C} 3 \mathrm{H} / \mathrm{HeJ}$ mice during myocardial I/R injury $(n=4)$. As shown in Figure 4, a small amount of 

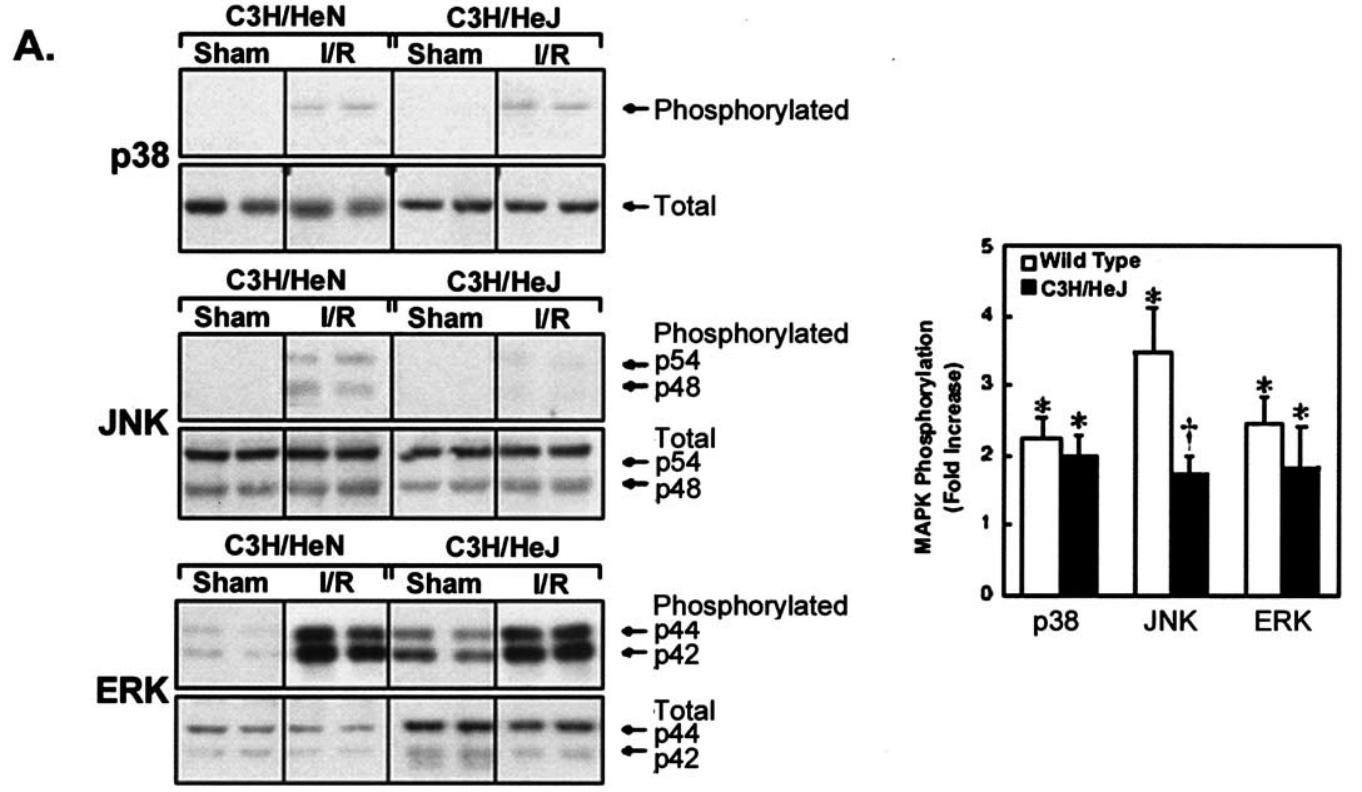

B.
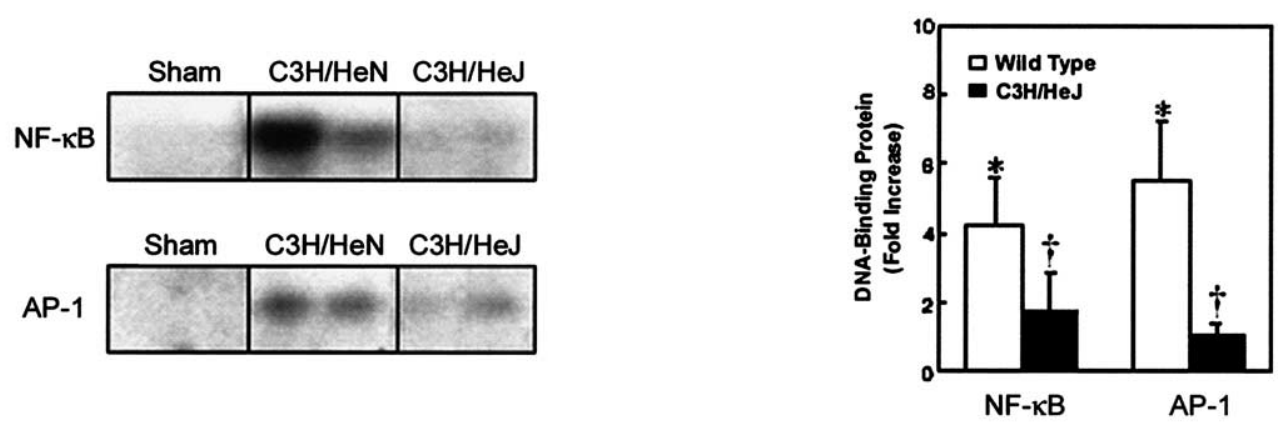

Figure 3. Western immunoblotting MAPK activation and EMSA nuclear translocation of NF- $\kappa$ B and AP-1 in myocardium from C3H/HeJ mice after myocardial I/R injury. Both C3H/HeN wild-type mice (WT) and C3H/HeJ TLR4 mutant mice were subjected to 60 minutes of ischemia. A, Western immunoblots are shown for p38 MAPK, JNK, and ERK compared with their respective nonischemic controls at 15 minutes of reperfusion. No differences were observed in the degree of activation between WT I/R and mutant $\mathrm{I} / \mathrm{R}$ for P38 MAPK or ERK $(P=N S)$. I/R also resulted in strong activation of JNK in WT and TLR4 mutant mice. However, the degree of activation of JNK was significantly reduced in the mutant mice $(P<.05)$. Two representative samples in each of the groups are shown $(n=5)$. Phosphorylation results are shown as -fold increase over control level. $B$, Nuclear myocardial protein samples from C3H/HeJ TLR4 mutant mice (mutant) and C3H/HeN wild-type mice (WT) were analyzed for NF- $\kappa$ B and AP-1 after 30 minutes of reperfusion. Myocardial $\mathbf{~} / \mathbf{R}$ resulted in activation of the transcription factors NF- $\kappa$ and AP-1 in both WT and mutant mice when compared with their respective nonischemic controls. However, the degree of activation was significantly reduced for both NF- $\kappa$ B and AP-1 in the TLR4 mutant mice $(P<.05)$. EMSA results are shown as -fold increase over the control level. *Significant increase over sham level; tsignificant decrease compared with the WT level.

TNF was induced in one wild-type mouse heart after myocardial I/R injury, but not in the other 3 experiments and in none of the 4 experiments with $\mathrm{C} 3 \mathrm{H} / \mathrm{HeJ}$ mice. Quantification of mRNA levels by densitometry revealed that the differences in expression of IL-1, MCP-1, and IL- 6 between $\mathrm{C} 3 \mathrm{H} / \mathrm{HeN}$ and $\mathrm{C} 3 \mathrm{H} / \mathrm{HeJ}$ strains were all significant $(P<$ $.05)$.

\section{Discussion}

We report a new, pathologic function for TLR4 and demonstrate the participation of TLR4 in myocardial I/R injury. To demonstrate the role of this receptor in injury of reperfused, ischemic myocardium, we used a strain of mice, $\mathrm{C} 3 \mathrm{H} / \mathrm{HeJ},{ }^{21}$ with a known spontaneous mutation in $t l r 4$, the gene encoding TLR4. ${ }^{22}$ This mutation, in the cytoplasmic 


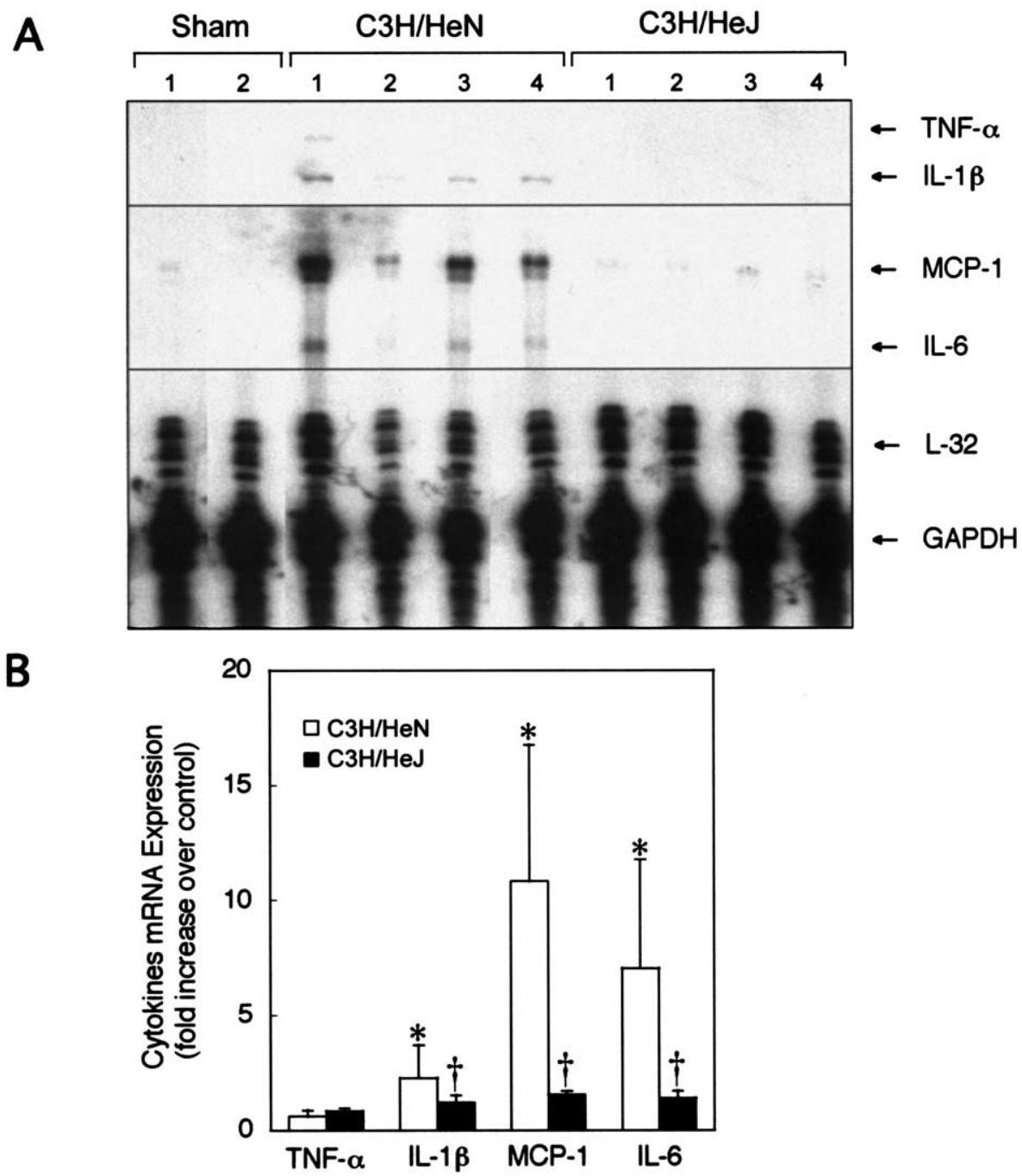

Figure 4. Ribonuclease protection assay for cytokine/chemokine mRNA expression. Regional myocardial l/R injury was induced in mouse hearts (as described in Materials and Methods) by 60 minutes of ischemia followed by 120 minutes of reperfusion. At the end of the reperfusion period, hearts were harvested and frozen. Myocardial RNA samples from sham-operated $\mathrm{C} 3 \mathrm{H} / \mathrm{HeN}$ mice, $\mathrm{C} 3 \mathrm{H} / \mathrm{HeN}$ wild-type mice (WT), and C3H/HeJ TLR4 mutant mice were then analyzed for (A) TNF- $\alpha$, IL-1 $\beta$, MCP-1, IL-6, control mRNA L-32, and glyceraldehyde-3-phosphate dehydrogenase (GAPDH). B, The expression of cytokines and chemokines (TNF- $\alpha$, IL-1 $\beta$, MCP-1, and IL-6) was induced in WT. However, the expression of IL-1 $\beta$, MCP-1, and IL-6 was significantly less in the TLR4 mutant mice compared with the WT mice $(P<.05)$. *Significant increase over sham level; tsignificant decrease compared with the WT level.

portion of TLR4, likely disrupts the engagement of TLR4 with adapter molecules that link TLR4 to downstream signaling pathways (Figure 5). IL-1 receptor signaling, which shares most of the same adapter molecules with TLR4, is predictably unaffected in $\mathrm{C} 3 \mathrm{H} / \mathrm{HeJ}$ mice. ${ }^{23}$ Additional proteins, CD14 and myeloid differentiation-2, are required for recognition of LPS by TLR4 at the cell surface. The complex of LPS, TLR4, CD14, and MD-2 is thought to induce dimerization and activation of TLR4. Once TLR4 is activated, the cytoplastic portion of the receptor joins with the adapter protein MyD88. MyD88 then attracts the protein kinase IL-1 receptor-associated kinase. IL-1 receptor-associated kinase is phosphorylated and activated during contact with MyD88 and in turn phosphorylates a third adapter, TNF-associated factor-6. TNF-associated factor- 6 is believed to activate MAPKs, which directly or indirectly activate a set of kinases that phosphorylate $\mathrm{I} \kappa \mathrm{B}$, thus targeting inhibitor $\kappa \mathrm{B}$ for degradation. Degradation of $\mathrm{I} \kappa \mathrm{B}$ releases NF- $\kappa \mathrm{B}$, which translocates into the nucleus, where it promotes the transcription of a wide variety of genes that 


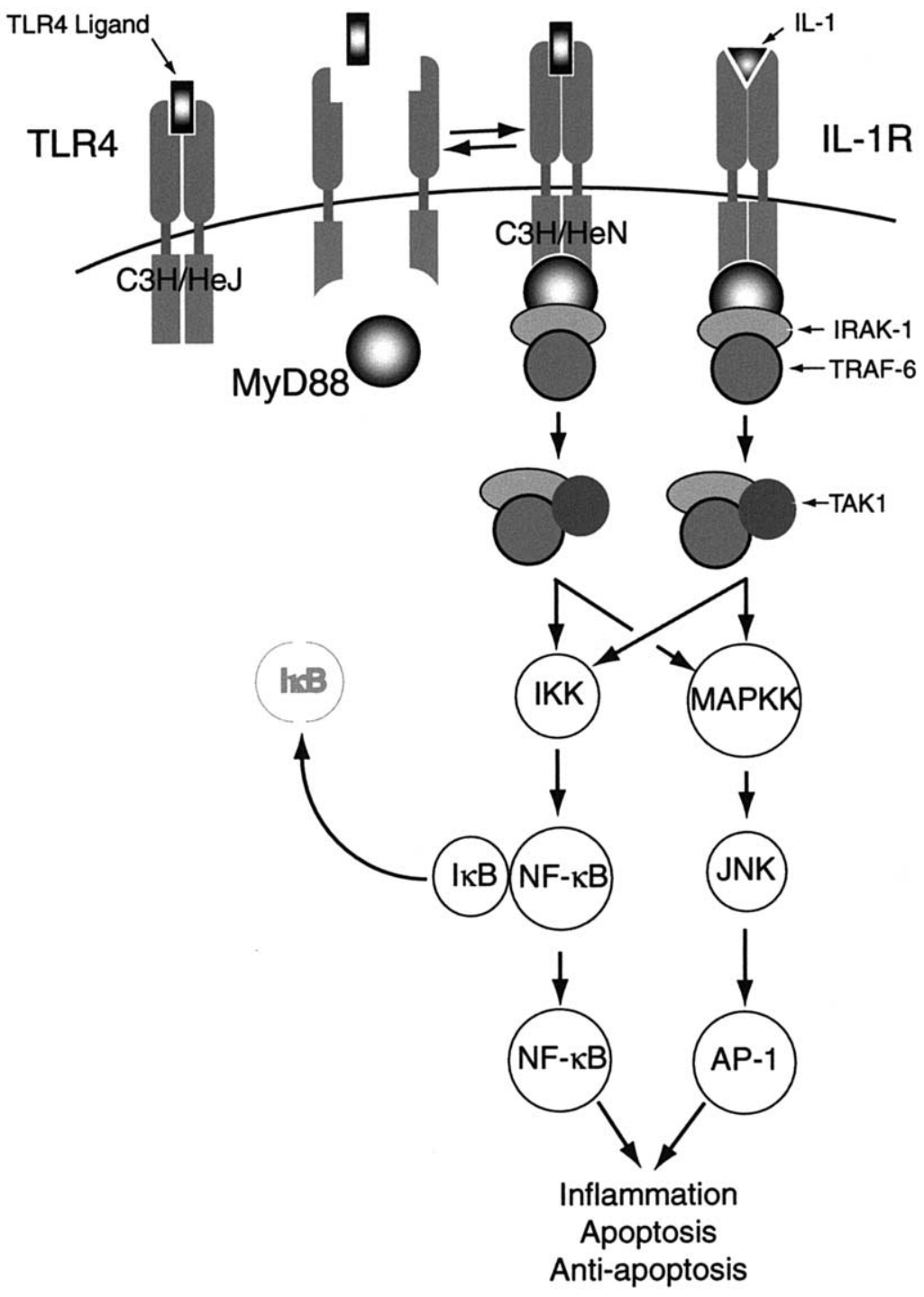

Figure 5. Activation of possible downstream signaling pathways by toll-like receptor (TLR)/interleukin-1 receptor (IL-1R) superfamily members. TLR4 (left) and IL-1R (right) are depicted in this figure showing an extracellular domain and a cytoplasmic domain for each. TLR/IL-1Rs are thought to cluster through the course of binding ligand; LPS interaction with TLR4 also requires CD14 and MD-2 (not shown). Presumably TLR4 and possibly other TLRs are activated by oxidative stress during myocardial $\mathrm{I} / \mathrm{R}$ injury, either by binding a putative endogenous ligand that circulates in response to myocardial $\mathbf{I} / \mathrm{R}$ injury or because of physical alteration by oxygen radical species of the receptor-plasma membrane environment, thus causing TLR4 activation in the absence of ligand. A receptor dimer recruits the adapter molecule MyD88. MyD88, in turn, recruits interleukin-1-associated kinase-1 (IRAK-1) and tumor necrosis factor receptor-associated factor-6 (TRAF-6) to form a signalosome. IRAK-1, TRAF-6, and other accessory molecules leave the cytoplasmic portion of TLR4 or IL-1R, and, at the plasma membrane, these adapters associate with TGF- $\beta$-activated kinase-1 (TAK1). TAK1 is a MAP kinase kinase that leads to JNK activation and AP-1 activity in the nucleus. TAK1 may also lead to the activation of $I_{\kappa} B$ kinase, which phosphorylates $I_{\kappa} B$, targeting $І_{\kappa} \mathrm{B}$ for degradation. NF- $\kappa \mathrm{B}$, freed of $\mathbf{I}_{\kappa} \mathrm{B}$ inhibition, translocates to the nucleus to promote the transcription of genes encoding proteins that mediate inflammation, apoptosis, or antiapoptotic pathways. TLR4 from $\mathrm{C} 3 \mathrm{H} / \mathrm{HeJ}$ is illustrated with an intact extracellular domain capable of binding ligand and a cytoplasmic domain incapable of recruitment of MyD88; in contrast, wild-type (C3H/HeN) does recruit MyD88 as the first step in TLR4 transmembrane signaling. 
encode proteins generally involved in the evolution of an inflammatory response or proteins that inhibit apoptotic cell death.

The mechanism of TLR 4 activation by oxidative stress in the absence of LPS remains to be elucidated. TLRs are now known to recognize certain host molecules, including fibrin and fibrinogen, HSP-60 and HSP-70, fibronectin, and components of the extracellular matrix., ${ }^{5,11}$ The apparent recognition by TLR4 of molecular structures other than LPS may explain activation of this receptor in the setting of myocardial I/R injury. During myocardial I/R injury, intracellular HSP-60 and HSP-70 may be released from dead or dying cells within the necrotic area of myocardium damage during ischemia. Extracellular HSPs may then diffuse into the surrounding ischemic zone during reperfusion and activate TLR4 on still-viable cells. The cellular events in cardiomyocytes that result in cytotoxicity and extension of the infarct remain to be identified. Similarly, TLR4-bearing cells within the AAR that regulate inflammation, such as monocytes, macrophages, and endothelial cells, may be activated through a TLR4 signal by the oxidative stress of myocardial I/R, leading to the initiation and advancement of an inflammatory response. An inflammatory response triggered by myocardial I/R injury, in theory, irreversibly damages potentially viable tissue surrounding an infarct, thereby further extending it.

Although $\mathrm{C} 3 \mathrm{H} / \mathrm{HeJ}$ mice are more susceptible to infection with gram-negative bacteria, TLR4 blockade has been examined as a treatment for endotoxemia. ${ }^{24-26}$ E5564 is a structural analog of the lipid A portion of LPS and is a potent antagonist of the biochemical and physiologic effects of LPS in several in vitro and in vivo models. E5564 is currently under clinical development as a possible therapeutic agent for the treatment of sepsis. ${ }^{26}$ Whether E5564 can block binding of non-LPS structures to TLR4 in myocardial $\mathrm{I} / \mathrm{R}$ injury remains to be determined.

\section{References}

1. Akira S, Takeda K, Kaisho T. Toll-like receptors: critical proteins linking innate and acquired immunity. Nat Immunol. 2001;2:675-80.

2. Poltorak A, He X, Smirnova I, Liu MY, Van Huffel C, Du X, et al. Defective LPS signaling in $\mathrm{C} 3 \mathrm{H} / \mathrm{HeJ}$ and $\mathrm{C} 57 \mathrm{BL} / 10 \mathrm{ScCr}$ mice: mutations in Tlr4 gene. Science. 1998;282:2085-8.

3. Qureshi ST, Lariviere L, Leveque G, Clermont S, Moore KJ, Gros P, et al. Endotoxin-tolerant mice have mutations in Toll-like receptor 4 (Tlr4). J Exp Med. 1999;189:615-25.

4. Hoshino K, Takeuchi O, Kawai T, Sanjo H, Ogawa T, Takeda Y, et al. Cutting edge: Toll-like receptor 4 (TLR4)-deficient mice are hyporesponsive to lipopolysaccharide-evidence for TLR4 as the Lps gene product. J Immunol. 1999;162:3749-52.

5. Termeer C, Benedix F, Sleeman J, Fieber C, Voith U, Ahrens T, et al. Oligosaccharides of Hyaluronan activate dendritic cells via toll-like receptor 4. J Exp Med. 2002;195:99-111.

6. Kawasaki K, Akashi S, Shimazu R, Yoshida T, Miyake K, Nishijima M. Mouse toll-like receptor 4. MD-2 complex mediates lipopolysaccharide-mimetic signal transduction by Taxol. J Biol Chem. 2000;275: 2251-4.

7. Dybdahl B, Wahba A, Lien E, Flo TH, Waage A, Qureshi N, et al.
Inflammatory response after open heart surgery: release of heat-shock protein 70 and signaling through toll-like receptor-4. Circulation. 2002;105:685-90.

8. Asea A, Rehli M, Kabingu E, Boch JA, Bare O, Auron PE, et al. Novel signal transduction pathway utilized by extracellular HSP70: role of toll-like receptor (TLR) 2 and TLR4. J Biol Chem. 2002;277:1502834.

9. Smiley ST, King JA, Hancock WW. Fibrinogen stimulates macrophage chemokine secretion through toll-like receptor 4. J Immunol. 2001;167:2887-94.

10. Ohashi K, Burkart V, Flohe S, Kolb H. Cutting edge: heat shock protein 60 is a putative endogenous ligand of the toll-like receptor-4 complex. J Immunol. 2000;164:558-61.

11. Okamura Y, Watari M, Jerud ES, Young DW, Ishizaka ST, Rose J, et al. The extra domain A of fibronectin activates Toll-like receptor 4. J Biol Chem. 2001;276:10229-33.

12. Gay NJ, Keith FJ. Drosophila Toll and IL-1 receptor. Nature. 1991; 351:355-6.

13. Medzhitov R, Preston-Hurlburt P, Janeway CA Jr. A human homologue of the Drosophila Toll protein signals activation of adaptive immunity. Nature. 1997;388:394-7.

14. Baumgarten G, Knuefermann P, Nozaki N, Sivasubramanian N, Mann DL, Vallejo JG. In vivo expression of proinflammatory mediators in the adult heart after endotoxin administration: the role of toll-like receptor-4. J Infect Dis. 2001;183:1617-24.

15. Frantz S, Kobzik L, Kim YD, Fukazawa R, Medzhitov R, Lee RT, et al. Toll4 (TLR4) expression in cardiac myocytes in normal and failing myocardium. J Clin Invest. 1999;104:271-80.

16. Schuster JM, Nelson PS. Toll receptors: an expanding role in our understanding of human disease. J Leukoc Biol. 2000;67:767-73.

17. Ravingerova T, Barancik M, Strniskova M. Mitogen-activated protein kinases: a new therapeutic target in cardiac pathology. Mol Cell Biochem. 2003;247:127-38.

18. Hampton CR, Shimamoto A, Rothnie CL, Griscavage-Ennis J, Chong A, Dix DJ, et al. HSP70.1 and -70.3 are required for late-phase protection induced by ischemic preconditioning of mouse hearts. Am J Physiol Heart Circ Physiol. 2003;285:H866-74.

19. Chen F, Demers LM, Vallyathan V, Ding M, Lu Y, Castranova V, et al. Vanadate induction of NF-kappaB involves IkappaB kinase beta and SAPK/ERK kinase 1 in macrophages. J Biol Chem. 1999;274: 20307-12.

20. Deisher TA, Sato TT, Pohlman TH, Harlan JM. A protein kinase C agonist, selective for the beta I isozyme, induces E-selectin and VCAM-1 expression on HUVEC but does not translocate PKC. Biochem Biophys Res Commun. 1993;193:1283-90.

21. Hepner G. High susceptibility of strain A mice to endotoxin and endotoxin-red blood cell mixtures. J Bacteriol. 1965;90:696-703.

22. Vogel SN, Johnson D, Perera PY, Medvedev A, Lariviere L, Qureshi ST, et al. Cutting edge: functional characterization of the effect of the $\mathrm{C} 3 \mathrm{H} / \mathrm{HeJ}$ defect in mice that lack an Lpsn gene-in vivo evidence for a dominant negative mutation. J Immunol. 1999; 162:5666-70.

23. Vogel SN, Douches SD, Kaufman EN, Neta R. Induction of colony stimulating factor in vivo by recombinant interleukin 1 alpha and recombinant tumor necrosis factor alpha 1. J Immunol. 1987;138: 2143-8.

24. Lynn M, Rossignol DP, Wheeler JL, Kao RJ, Perdomo CA, Noveck $\mathrm{R}$, et al. Blocking of responses to endotoxin by E5564 in healthy volunteers with experimental endotoxemia. J Infect Dis. 2003;187: 631-9.

25. Bunnell E, Lynn M, Habet K, Neumann A, Perdomo CA, Friedhoff LT, et al. A lipid A analog, E5531, blocks the endotoxin response in human volunteers with experimental endotoxemia. Crit Care Med. 2000;28:2713-20.

26. Wong YN, Rossignol D, Rose JR, Kao R, Carter A, Lynn M. Safety, pharmacokinetics, and pharmacodynamics of E5564, a lipid A antagonist, during an ascending single-dose clinical study. J Clin Pharmacol. 2003;43:735-42. 


\section{Discussion}

Dr Robert C. Robbins (Stanford, Calif). I had never heard of TLR4 before getting this abstract from the program committee, so I appreciate the opportunity to be educated in this area. Dr Chong has done a very nice job in his opening remarks to discuss toll-like receptors, which are recently discovered transmembrane receptor proteins that play a central role both in the inflammatory process and in the innate and inductive immunity process. As he pointed out, most of the studies that I could find in the literature are based on septic shock, but the objective of his study was to try to better understand the involvement of TLR4 in I/R injury in the myocardium.

He used wild-type animals and then a transgenic animal that reduced the capability of toll-like receptor function, and he observed that toll-like receptor mutant mice had significantly less myocardial injury as manifested by reduction in myocardial infarct size, cell signaling proteins, transcription factor, and cytokines that are associated with $\mathrm{I} / \mathrm{R}$ injury than did the control animals.

To comment technically about this study, I will just say that this work was done by beating heart ligation of the LAD in 25-g mice. These mice are about the size of the end of my finger and 10 times smaller than most of the rats that we normally operate on. Technically it is a tour de force to even accomplish this model.

Second, the molecular biology is just another reflection of Dr Verrier's incredible laboratory and the infrastructure he has. The information was well presented and the quality of the gels was outstanding. I was able to find only 2 articles in the surgical literature concerning TLR4. One is a recent article from the University of Toronto that demonstrated that the oxidative stress of hemorrhagic shock contributed to regulation of TLR4 mRNA expression, and then Magdi Yacoub's group has demonstrated that TLR4 expression was significantly increased in patients requiring left ventricular assist device support compared with stable patients with advanced heart failure who received cardiac transplantation. However, the current study is novel and significant because it is the first report, as Dr Chong has indicated, of the importance of toll-like receptor in myocardial I/R injury. As the authors correctly indicate, this new knowledge may lead to potential therapeutic strategies for the reduction of myocardial injury associated with reperfusion injury.

Dr Chong, I have just a few brief comments and questions. Do you have any comment about future plans or why you did not do any echocardiograms or $\mathrm{dp} / \mathrm{dt}$ in these mice?

Dr Chong. Thank you for those kind comments, Dr Robbins. Our in vivo model used infarction size as a measure of myocardial injury. Our model is capable of producing reproducible results and allowing us to really measure what the extent of the damage from $\mathrm{I} / \mathrm{R}$ injury is. The other variables such as $\mathrm{dp} / \mathrm{dt}$ and also echocardiograms would only add to the data, and we are actually in the process of acquiring an ultrasound machine that would actually help us do that. Measurement of $\mathrm{dp} / \mathrm{dt}$ and other hemodynamic parameters would require us to purchase other equipment to measure that in an in vivo setting. We have thought about that and we thought that the measurement of infarction size was sufficient.

Dr Robbins. I think your next level of this work is going to be to actually allow the animals to survive and look at long-term functional data. Your answer might sound like a cop-out to some people, but at Stanford there is one $15-\mathrm{MHz}$ probe and we have an incredible time trying to get our animals imaged. I agree with you that it is a big expense and it is very tough to do, but I thought I would bring it up.

Have you measured the actual toll-like receptor protein expression in your animals and is it possible to create a total knock-out of this gene or would they just not survive?

Dr Chong. Another excellent question. First, the expression of TLR4 has been shown in some studies. These studies concentrate on the heart that has been damaged by ischemia chronically, and they show that the expression of TLR4 over several days and weeks is increased in the cardiomyocytes in points where the cells are juxtaposed. In our model we have not done so. It would require us to do an in situ hybridization for mRNA levels of TLR4 because the time alloted for during ischemia and reperfusion we believe is not enough to have de novo synthesis of TLR4 and to bring it up to the surface.

The second answer is, yes, it is possible to have transgenic mice with targeted deletion of TLR4. In fact, we are just about to get those mice in addition to mice that have targeted deletion of very proximal signaling molecules for all the toll-like receptors and not just TLR4. Further, we are also collaborating with several pharmacologic companies that have antagonists to TLR4 and are now proceeding with clinical studies in sepsis. Our preliminary results in our model show very promising results.

Dr Robbins. Why do you think you observed a reduction in JNK kinase but not in p38 and ERK?

Dr Chong. That's a great question. Myocardial I/R has been shown in the literature to activate all 3 classes of MAP kinases, p38, ERK, and JNK. As you know, activation of MAP kinase is very complex and it is not as simple as I have shown here. The activation of these kinases, as well as the signaling molecule targets of these kinases, varies not only on the identity of the signal but also on the duration, the strength, and the location. Because the inflammatory response in myocardial $I / R$ is so redundant, we found that surprising to have found a reduction in JNK at all. It seems that the protection we see from inhibiting TLR4 signaling comes exclusively through JNK signaling, and we hope to investigate this further by looking at similar studies in transgenic mice with targeted deletion of TLR4 as well as MYD88 and also MAP kinase, kinase 3 and 6 deletions, which are the kinases for the MAP-kinases. Those are the ones that exclusively control JNK.

Dr Robbins. Nowhere in the literature could I find information about antagonists to toll-like receptors, so you speculated this might be useful in clinical strategies. How would you plan for us to do that? Would it be an antibody or how would we prevent toll-like receptor in a clinical setting?

Dr Chong. Cellularly, the antagonist binds TLR4 and prevents basically further downstream signaling. The first known adaptor molecule to this receptor is called MYD88, and that is crucial to the further downstream events of this receptor. Blocking it with a specific antagonist would block the recruitment of this adaptor molecule. We believe that this antagonist can be used in a variety of settings, settings in which I/R events are involved, such as organ transplantation, cardiopulmonary bypass, when you arrest the heart during cardiac surgical procedures, during revascularization procedures, and so forth.

Dr Thomas Maxey (Charlottesville, Va). Dr Chong, you and Dr Verrier again have set the mark for I/R research. As you know, 
the complex pathway of I/R injury involves certainly many receptors and intracellular mediators. You have beautifully demonstrated that this TLR4 down-regulates some of the intracellular things, such as $\mathrm{p} 38$. Did you measure any of the end products of TNF- $\alpha$ and cellular adhesion molecules and things even more downstream from NF- $\kappa$ B to see whether those were down-regulated as well?

Dr Chong. We measured mRNA levels of proinflammatory mediators like those you are talking about-TNF- $\alpha$, interleukins, adhesion molecules. As I have demonstrated in the ribonuclease protection assay, which actually is a gel of looking at mRNA levels, it was all up-regulated in the wild-type mice, and by all I mean MCP-1, IL-6, and IL-1 $\beta$. In fact, there were actually others that I did put up on the gel just for the sake of simplification, but with TLR4 mutation all these levels were decreased. Now we are planning to measure not just mRNA levels but also protein levels as well as mRNA levels by in situ hybridization within the cell so that we know which cell type these proteins come from. To do that, we have to extend our reperfusion times long enough to have de novo protein synthesis from the mRNA, and that will require longer reperfusion times. There are some technical difficulties with making the mice survive long enough for us to explant the heart.

\section{JTCVS On-Line Manuscript Submission and Review}

\section{Please visit http://www.editorialmanager.com/jtcvs/}

Effective September 15, 2001, authors and reviewers may submit manuscripts and reviews electronically via Editorial Manager, our new Web-based system with full electronic submission, review, and status update capabilities.

As we move from paper to electronic submissions, the Editorial Office will make proxy submissions of all manuscripts accompanied by a diskette containing the electronic files of the text, tables, and figures. Editors, authors, and reviewers will receive automatic e-mails when significant events occur.

We strongly encourage all authors and reviewers to use Editorial Manager. Although we will continue to accommodate the submission of paper manuscripts for some months, our goal is to be completely electronic within 9 to 12 months.

All individuals currently in our database for whom we have e-mail addresses will receive via e-mail a system-assigned username and password that can be used to log in to the system without prior registration. All those not receiving the e-mail must register the first time they use the system.

As with any broad systemic change, the conversion to the new system will take some time to complete. We ask your patience as we replace our in-office database with the new system. We also encourage you to take advantage of the speed and efficiency that the new system will provide for us all: editor, author, reviewer, and publisher. 